\title{
Impact of Fermented Liquid Potato Hash Diets on Growth Performance of Grower Pigs
}

\author{
Ronald Sylvester Thomas ${ }^{1,2}$, Arnold Tapera Kanengoni ${ }^{3,4}$ \& Michael Chimonyo ${ }^{2}$ \\ ${ }^{1}$ Agricultural Research Council-Animal Production Institute Pig Nutrition, Irene, South Africa \\ 2 Animal and Poultry Science, School of Agricultural, Earth and Environmental Sciences, University of \\ KwaZulu-Natal, Scottsville, Pietermaritzburg, South Africa \\ ${ }^{3}$ Joburg Zoo, Parkview, South Africa \\ ${ }^{4}$ College of Agriculture and Environmental Sciences, University of South Africa, Florida Campus, Florida, South \\ Africa \\ Correspondence: Ronald Sylvester Thomas, Animal and Poultry Science, School of Agricultural, Earth and \\ Environmental Sciences, University of KwaZulu-Natal, Private Bag X01, Scottsville 3209, Pietermaritzburg, \\ South Africa. Tel: 27-12-672-9304. E-mail: ronaldt@arc.agric.za
}

Received: September 30, 2017

Accepted: January 30, 2018

Online Published: May 15, 2018

doi:10.5539/jas.v10n6p1

URL: https://doi.org/10.5539/jas.v10n6p1

\begin{abstract}
The study aimed to evaluate growth performance of grower pigs fed fermented liquid potato hash with or without exogenous enzyme. Diets containing either 200 (LFLPH) g/kg potato hash (enzyme treated or not); 400 (HFLPH) g/kg potato hash (enzyme treated or not) or no fermented potato hash (control) were formulated to provide $14 \mathrm{MJ} / \mathrm{kg}$ digestible energy (DE), $180 \mathrm{~g} / \mathrm{kg}$ crude protein (CP) and $11.6 \mathrm{~g} / \mathrm{kg}$ lysine. Dietary treatments were control (no FLPH), enzyme treated LFPHE and HFLPHE, and untreated LFLPH and HFLPH. The exogenous enzyme was added in treated diets to provide minimum of 560-840 TXU/TDU xylanase per kg feed, at an inclusion rate of $100 \mathrm{~g} /$ tonne. Diets were mixed with water at $1: 2$ ration and fermented for 8 hours at $25{ }^{\circ} \mathrm{C}$ room temperature before being fed to pigs. Back-slopping fermentation approach was followed to prepare diets. Twelve pigs $(25 \pm 2.3 \mathrm{~kg})$ per diet that were individually housed were fed ad-lib for eight weeks. Pigs were allocated to diets in complete randomized design. Average daily gain (ADG), average daily feed intake (ADFI) and feed conversion ratio (FCR) were measured. The enzyme treated FLPH diets had higher $(\mathrm{P}<0.05) \mathrm{CP}$, lower $(\mathrm{P}>0.05) \mathrm{NDF}$ and ADF concentrations compared to untreated FLPH diets. The LFPHE diet had higher $(\mathrm{P}<$ 0.001) final weight, ADG and lower $(\mathrm{P}<0.001)$ ADFI and FCR compared to LFPH, HLFPH and HLFPHE. It was concluded that LFPHE diet may be an alternative feed source for growing pigs as indicated by higher gain and lower intake compared to LFLPH, HFLPH and HFLPHE.
\end{abstract}

Keywords: fermentation liquid feed, potato hash, grower pigs, exogenous enzyme

\section{Introduction}

In South Africa, the declining grain production and increasing competition with humans for feed ingredients have compelled smallholder pig farmers to use alternative energy sources from agro-industrial by-products to replace cereals in pig diets (Nkosi et al., 2010; Thomas et al., 2010). By-products of industrial potato processing such as potato hash are a potential energy resource, which could replace or be included in traditional pig diets (Thomas et al., 2010). According to Thomas et al. (2010), potato hash is a potato by-product produced during processing of Simba chips in Gauteng province, South Africa. The hash is produces at a rate of \pm 50 tons per day and is currently dumped (Nkosi \& Meseke, 2010) and is polluting the environment. However, this by-product contains $150 \mathrm{~g} / \mathrm{kg}$ dry matter, $105 \mathrm{~g} / \mathrm{kg}$ crude protein and $58.5 \mathrm{~g} / \mathrm{kg}$ crude fiber (Nkosi et al., 2015) and can be useful as pig feed. According to Charmley et al. (2006) and Okine et al. (2005), high moisture content of potato by-products such as potato hash is limiting the utilization of the by-products in pig nutrition. Another setback in feeding potato hash to growing pigs is that it contains high fiber content (Thomas et al., 2010). Kanengoni et al. (2004) and Fevrier et al. (1992) reported that high fiber diets in growing pigs' increases rate of passage. In addition, high fiber diets reduces digestion and rate of nutrients absorption (Wenk, 2001). Fermentation of high fiber by-products and use of exogenous enzymes have been reported to disrupt the fibre matrix structure 
enabling further breakdown of fiber components of the diet (Le Gall et al., 2009; Zhang et al., 2010; Urriola et al., 2010). Therefore the study proposes to ferment and feed potato hash as a liquid feed.

Liquid fermented feed (LFF) has been defined as a mixture of feed (dry feed, by-products) with water at a ratio ranging from 1:1.4 to 1.5 and fermented for a minimum of 8 hours before being fed to the pigs (Canibe \& Jensen, 2003). Feeding LFF has been reported to reduce several pathogens along gastrointestinal-tract (GI-tract) of growing pigs (Hong et al., 2009). Also, Brooks (2008), and Canibe and Jensen (2003) reported higher growth performances when pigs were fed LFF. Enzymes have been used as additives, and have been incorporated in high moisture by-products to reduce DM losses and improve nutritive value of the diet (Nkosi et al., 2015; Urriola et al., 2010). Addition of exogenous enzymes in the diet degrade fiber to fermentable water-soluble carbohydrates (WSC) for use by LAB (Eun \& Beauchemin, 2007). The LAB in the diet will inhibit exogenous enzyme activities against structural carbohydrates in fermented diets (Xing et al., 2009). Therefore, the aim of the study was to evaluate growth performance of Large White $\times$ Landrace crossbred pigs fed varying levels of fermented liquid potato hash diets treated with or without exogenous xylanase feed enzyme (Natugrain TS L®).

\section{Materials and Methods}

\subsection{Location and Experimental Area}

The study was conducted at the Pig Nutrition Research Unit of Agricultural Research Council (ARC), Animal Production (AP), (ARC-AP: Irene, Pretoria, South Africa). The ARC-AP campus is located at $25^{\circ} 55^{\prime}$ South; $28^{\circ} 12^{\prime}$ East. The campus is located in the Highveld region of South Africa and situated at an altitude of $1525 \mathrm{~m}$ above sea level. Potato hash (PH) was collected from Simba (Isando, Gauteng, South Africa), a potato chips factory in South Africa for production of fermented liquid potato hash diet (FLPH). The study was approved by the Agricultural Research Council Animal Ethics committee (Reference Number: APIEC16/005).

\subsection{Fermentation Process and Diets}

A back-slopping fermentation approach was used to prepare fermented liquid potato hash diets as described by Plumed-Ferrer and Von Wright (2009). Fermented liquid diets were prepared by mixing potato hash diets with water, at a ratio of 1:2. The composition of the potato hash before fermenting is shown in Table 1. Five diets (Table 2) were formulated to be isoenergetic and isonitrogenous containing either 200 (LFLPH) g/kg potato hash (enzyme treated or not); $400(\mathrm{HFLPH}) \mathrm{g} / \mathrm{kg}$ potato hash (enzyme treated or not) or no fermented potato hash (control). The diets were formulated to provide $14 \mathrm{MJ} / \mathrm{kg}$ digestible energy (DE), $180 \mathrm{~g}$ crude protein $(\mathrm{CP}) / \mathrm{kg}$ and $11.6 \mathrm{~g}$ lysine $/ \mathrm{kg}$ which meet and exceed the requirements of growing pigs (NRC, 1998). The five dietary treatments were: control (no FLPH), enzyme treated LFPHE and HFLPHE, and untreated LFLPH and HFLPH. The exogenous xylanase enzyme (Natugrain TS L $®$ ) was added in the diets before fermenting diets to provide a minimum enzyme activity of 560-840 TXU/TDU xylanase per kg feed, at an inclusion rate of $100 \mathrm{~g} /$ tonne. The fermented diets were stored in closed $100 \mathrm{~L}$ drums under agitation at $25^{\circ} \mathrm{C}$ for 8 hours before being fed to the pigs. Pigs were adapted to diets for a period of ten days. The pigs were fed ad libitum for eight weeks and water was made available at all times through drinking nipples.

Table 1. Composition of potato hash $(\mathrm{g} / \mathrm{kg} \mathrm{DM})$ pre-fermentation $(\mathrm{n}=3)$

\begin{tabular}{ll}
\hline Parameter & Mean \pm SD \\
\hline Dry matter, g/kg & $374 \pm 0.92$ \\
Crude protein, g/kg DM & $192 \pm 0.88$ \\
Gross energy MJ/kg DM & $18.9 \pm 0.74$ \\
aNDF, g/kg DM & $468 \pm 0.98$ \\
Acid detergent fibre, g/kg DM & $129 \pm 0.87$ \\
Water soluble carbohydrates, g/kg DM & $79 \pm 0.71$ \\
pH & $5.05 \pm 0.54$ \\
\hline
\end{tabular}

Note. aNDF, amylase-treated neutral detergent fibre.

\subsection{Pigs, Experimental Design and Housing}

Sixty (12 pigs per treatment) crossbred pigs (Large White $\times$ Landrace) aged 55 days with an average weight of $25.5 \pm 3 \mathrm{~kg}$ were randomly selected from the ARC-AP Irene, pig breeding unit. Pigs were allocated to dietary treatments in a completely randomized design. The pigs were housed individually in $1.54 \times 0.8 \mathrm{~m}$ pens in 
environmentally controlled houses with the temperature ranging from 22 to $25^{\circ} \mathrm{C}$. The feeders were checked and adjusted twice each day to ensure constant access to fresh feed and minimize any possible wastage.

\subsection{Chemical Composition Analysis}

Diets were analysed in triplicate, in the Animal and Poultry Science Laboratory at the University of KwaZulu-Natal, Pietermaritzburg. Dry matter (DM) content was determined by oven-drying the samples at $65{ }^{\circ} \mathrm{C}$ for 48 hours. The ash content was determined after incineration of the sample at $550{ }^{\circ} \mathrm{C}$ for 4 hours according to method 990.05 (AOAC, 1990). Dry samples were ground through a $1 \mathrm{~mm}$ screen (Wiley mill, Standard Model 3, Arthur H. Thomas Co., Philadelphia, PA, USA) for chemical analyses. The neutral detergent fibre (NDF) and acid detergent fibre (ADF) contents were determined following the procedures of Van Soest et al. (1991) using ANKOM Fibre Analyser (Ankom, Macedon, NY, USA). Separate samples were used for ADF and amylase-treated neutral detergent fibre (aNDF) analyses and both included residual ash. The GE was determined with bomb calorimetry (MS-1000 modular calorimeter, Energy Instrumentation, Centurion, South Africa).

\subsection{Measurements}

During the study, the pigs were weighed individually on a weekly basis to determine daily body weight gain. Daily feed offered and weekly orts were recorded. The orts were dried, weighed and discarded daily. Weights of feed refusals and orts were subtracted from the total weight of the feed allocated to determine feed intake for that week. Weight of the feed consumed each week was divided by seven to determine the average daily feed intake. Feed was supplied ad libitum and water was made available at all times through drinking nipples.

Table 2. Composition of varying inclusion levels of fermented liquid potato hash (as-is basis)

\begin{tabular}{|c|c|c|c|}
\hline & \multicolumn{3}{|c|}{ Experimental diets $^{1}$} \\
\hline & $\mathrm{CON}$ & LLFPH & HLFPH \\
\hline \multicolumn{4}{|l|}{ Ingredient, $\mathrm{kg}$} \\
\hline Hominy Chop & 608.7 & 504.4 & 400 \\
\hline Molasses & 20 & 15 & 10 \\
\hline Potato hash & 0 & 200 & 400 \\
\hline Soybean oilcake & 181.4 & 166.7 & 152.1 \\
\hline Corn meal & 150 & 75 & 0 \\
\hline Monocalcium phosphate & 5 & 8.1 & 11.2 \\
\hline Limestone & 18.8 & 16.3 & 13.7 \\
\hline Lysine $\mathrm{HCl}$ & 8 & 6.5 & 5 \\
\hline Salt & 4 & 4 & 4 \\
\hline Vitamin-mineral premix ${ }^{2}$ & 4 & 4 & 4 \\
\hline \multicolumn{4}{|l|}{ Nutrients, g/kg } \\
\hline $\mathrm{DM}$ & 892 & 605 & 599 \\
\hline Ash & 25 & 31 & 37 \\
\hline $\mathrm{CP}$ & 180 & 180 & 180 \\
\hline Crude fibre & 57 & 58 & 60 \\
\hline Calcium & 9.12 & 9.12 & 9.12 \\
\hline Phosphorus & 5.47 & 5.46 & 5.46 \\
\hline Lysine & 11.6 & 11.6 & 11.6 \\
\hline Methionine & 0.67 & 0.56 & 0.56 \\
\hline $\mathrm{DE}, \mathrm{MJ} / \mathrm{kg}$ & 13.5 & 13.5 & 13.5 \\
\hline
\end{tabular}

Note. ${ }^{1} \mathrm{CON}=$ control (liquid fermented control with and without enzyme); LLFPH $=$ low inclusion of liquid fermented potato hash with and without enzyme; HLFPH = high inclusion of liquid fermented potato hash with and without enzyme. ${ }^{2}$ Provided the following per $\mathrm{kg}$ of diet: 6,500 IU vitamin A, 1,200 IU vitamin D3, $40 \mathrm{IU}$ vitamin E, 2 mg vitamin K3, 1-5 mg vitamin B1, 4.5 mg vitamin B2, $0.03 \mathrm{mg}$ vitamin B12, $2.5 \mathrm{mg}$ vitamin B6, $25 \mathrm{mg}$ niacin, $12 \mathrm{mg}$ calcium pantothenate, $190.5 \mathrm{mg}$ choline, $0.6 \mathrm{mg}$ folic acid, $0.05 \mathrm{mg}$ biotin, $40 \mathrm{mg}$ manganese, $100 \mathrm{mg}$ zinc, $125 \mathrm{mg}$ copper, $1 \mathrm{mg}$ iodine, $100 \mathrm{mg}$ ferrous, and $0.3 \mathrm{mg}$ selenium. 


\subsection{Statistical Analyses}

Data of growth performance of grower pigs fed fermented liquid potato hash diets treated with or without enzyme were analysed for effects of treatment using General Linear Model (SAS Inst. Inc., Cary, NC). All data were tested for normality and homogeneity and comparisons were made to the $95 \%$ significance level. The model used was:

$$
\text { Yijkl }=\mu+\alpha i+\beta j+(\alpha \times \beta) i j+\varepsilon i j k
$$

where,

Yijkl is the performance parameter (ADFI, ADG and FCR); $\mu$ is the overall mean response common to all observations; $\alpha \mathrm{i}$ is the effect of fermentation ( $\mathrm{i}=$ treatments); $\beta \mathrm{j}$ is the effect of enzyme $(\mathrm{j}=\mathrm{E}) ;(\alpha \times \beta) \mathrm{ij}$ is the interaction between the enzyme and inclusion level and cijk is the residual error.

\section{Results and Discussion}

Chemical composition of diets based on varying inclusion levels of fermented liquid potato hash treated with or without enzyme are shown in Table 3. Control diet had a higher $(\mathrm{P}<0.05)$ dry matter $(\mathrm{DM})$ and ash concentrations compared to diets containing varying levels of FLPH. The enzyme treated FLPH diets had higher $(\mathrm{P}<0.05) \mathrm{DM}$ and ash concentrations compared to untreated FLPH diets. Ideal, dry matter content of fermented liquid diets range from 200 to $300 \mathrm{~g} / \mathrm{kg}^{-1}$ (de Lange et al., 2006) and the results of this study are consistent with those findings. The DM content influence the quality of the resulting of fermented liquid diets. The enzyme treated FLPH diets had a lower $(\mathrm{P}>0.05) \mathrm{NDF}$ and ADF concentrations compared to untreated FLPH diets. Reduced fibre content with enzyme treated fermented liquid potato hash compared to untreated fermented liquid potato hash are consistent with previous observations on enzyme-treated fermented potato pulp diet ( $\mathrm{Li}$ et al., 2011). The reduction in fibre content (NDF and ADF) with enzyme treated fermented liquid potato hash could be attributed to hydrolysis of hemicelluloses (Muck \& Kung, 1997). These results, support studies that recorded reduced fiber content with enzyme treatment (Nkosi et al., 2011, 2015). There was no difference $(P>0.05)$ between treated and untreated FLPH diets on gross energy (GE) and ether extract (EE) concentrations. Control had a greater $(\mathrm{P}<0.05)$ crude protein $(\mathrm{CP})$ compared to FLPH diets. However, enzyme treated FLPH diets had a higher $(\mathrm{P}<0.05)$ CP than untreated FLPH diets. Nkosi et al. (2015) also reported higher CP content on enzyme-treated diets which are consistent with the results of the current study. The $\mathrm{CP}$ increase could be due to the disappearance of dietary components (easily fermentable carbohydrates) during fermentation (Scholten et al., 2002; Canibe \& Jensen, 2003). In addition, there were no differences $(P>0.05)$ in diet $\times$ enzyme interactions on GE, EE and CP between diets containing varying levels of FLPH diets treated with or without enzyme.

Højberg et al. (2003) and Brooks et al. (2003) reported that fermented liquid diets reduced incidence of diarrhoea when fed to growing pigs. In the current study, pigs fed on fermented liquid potato hash did not have diarrhoea compared to control were three pigs were treated for diarrhoea which is consistent with those studies. Growth performance of growing LW $\times$ LR crossbred pigs fed diets containing varying levels of FLPH treated with or without enzyme are shown in Table 4. There was no difference between LFLPHE and control diets on final weight, ADG, ADFI and FCR. The LFLPHE had higher $(\mathrm{P}<0.05)$ average daily gain $(\mathrm{ADG})$ and lower $(\mathrm{P}<$ 0.05 ) average daily feed intake (ADFI) and feed conversion ratio (FCR) compared to pigs fed diets containing LFLPH, HFLPH and HFLPHE. The fermented liquid diets treated with enzyme improved $(\mathrm{P}<0.05)$ feed intake of grower pigs compared to LFPH, HLFPH and control treatments. There were diet $\times$ enzyme interactions for ADG and FCR in the growing pigs. The current study is in agreement with studies (Kim et al., 2001; Choct et al., 2004; Han et al., 2006), that reported improved growth performance of grower pigs fed fermented liquid diets. Grower pigs when fed concentrates diets can record minimum daily gains of $630 \mathrm{~g}$ per day ${ }^{-1}$ (Hoffman et al., 2003). However, the present study recorded daily gains of $>720 \mathrm{~g}_{\text {day }}{ }^{-1}$ which was higher than those reported in a previous study (Thomas et al., 2010) when 200 and $400 \mathrm{~g} \mathrm{~kg}^{-1}$ potato hash diets were included in the diet of grower pigs. In addition, Nkosi et al. (2010) also recorded lower daily gains $<120 \mathrm{~g} \mathrm{day}^{-1}$ when total mixed potato hash ration with or without bacterial inoculation was fed to growing crossbred (Large White $\times$ Landrace) pigs. The current study reported a higher DMI for pigs fed low fermented liquid potato hash diet, which may be the reason for an improved ADG compared with pigs fed the control diet which is consistent with study by Brooks et al. (2003). 
Table 3. Chemical composition (g/kg DM feed) varying inclusion levels of fermented liquid potato hash with or without exogenous enzyme $(n=3)$

\begin{tabular}{llllllllll}
\hline \multirow{2}{*}{ Composition $^{2}$} & \multicolumn{1}{c}{ Treatments $^{1}$} \\
\cline { 2 - 10 } & Control & LLFPHE & LFPH & HLFPHE & HLFPH & SEM & Diet & Enzyme & Diet $\times$ Enzyme \\
\hline Dry matter g/kg DM & $904.7^{\mathrm{a}}$ & $294.5^{\mathrm{bc}}$ & $284.7^{\mathrm{c}}$ & $260.4^{\mathrm{d}}$ & $256.3^{\mathrm{d}}$ & 0.189 & $<.0001$ & $<.0001$ & $<.0001$ \\
Ash g/kg DM & $62.0^{\mathrm{a}}$ & $53.6^{\mathrm{bc}}$ & $51.1^{\mathrm{bc}}$ & $41.1^{\mathrm{c}}$ & $40.6^{\mathrm{c}}$ & 0.209 & $<.0001$ & $<.0001$ & $<.0001$ \\
Gross energy (MJ/kg) & 18.1 & 17.9 & 17.9 & 17.9 & 17.8 & 0.656 & 0.326 & 0.605 & 0.728 \\
Ether extract g/kg DM & 49.0 & 48.5 & 44.5 & 38.9 & 37.5 & 4.14 & 0.048 & 0.688 & 0.679 \\
Crude protein g/kg DM & $194.0^{\mathrm{a}}$ & $193.5^{\mathrm{a}}$ & $186.5^{\mathrm{c}}$ & $190.0^{\mathrm{b}}$ & $178.0^{\mathrm{d}}$ & 1.13 & $<.0001$ & 0.171 & 0.495 \\
Density $(\mathrm{g} \mathrm{DM} / \mathrm{ml})$ & 1.4 & 1.5 & 1.6 & 1.6 & 1.6 & 1.69 & 0.445 & 0.812 & 0.257 \\
NDF $(\mathrm{g} / \mathrm{kg} \mathrm{DM})$ & $132.1^{\mathrm{d}}$ & $202.2 \mathrm{~d}$ & $244.8^{\mathrm{c}}$ & $418.1^{\mathrm{b}}$ & $465.9^{\mathrm{a}}$ & 1.99 & $<.0001$ & $<.0001$ & $<.0001$ \\
ADF $(\mathrm{g} / \mathrm{kg} \mathrm{DM})$ & $39.1^{\mathrm{e}}$ & $71.3^{\mathrm{d}}$ & $80.1^{\mathrm{c}}$ & $98.9^{\mathrm{b}}$ & $106.85^{\mathrm{a}}$ & 0.085 & $<.0001$ & 0.002 & 0.020
\end{tabular}

Note. ${ }^{\text {abc }}$ Values with different superscripts within a row are different $(\mathrm{P}>0.0001)$; ${ }^{1} \mathrm{CON}=\mathrm{Control}$ diet; LLFPHE $=$ Low liquid fermented potato hash with enzyme diet, LLFPH $=$ Low liquid fermented potato hash without enzyme diet, HLFPH = High liquid fermented potato hash with enzyme diet, HLFPH $=$ High liquid fermented potato hash without enzyme diet. ${ }^{2} \mathrm{NDF}=$ neutral detergent fibre; $\mathrm{ADF}=$ acid detergent fibre.

Table 4. Growth performance of growing Large White $\times$ Landrace $(\mathrm{LW} \times \mathrm{LR})$ pigs fed varying inclusion levels of fermented liquid potato hash with or without exogenous enzyme $(n=9)$

\begin{tabular}{llllllllll}
\hline \multirow{2}{*}{ Parameters $^{2}$} & \multicolumn{7}{c}{ Treatments $^{1}$} \\
\cline { 2 - 10 } & CON & LLFPHE & LLFPH & HLFPHE & HLFPH & SEM & Diet & Enzyme & Diet×Enzyme \\
\hline IW (kg) & 24.50 & 22.98 & 22.33 & 21.15 & 22.37 & 5.61 & 0.785 & 0.991 & 0.903 \\
FW (kg) & $77.55^{\mathrm{a}}$ & $75.29^{\mathrm{a}}$ & $66.87^{\mathrm{bc}}$ & $62.06^{\mathrm{cd}}$ & $56.90^{\mathrm{d}}$ & 7.12 & 0.0001 & 0.952 & 0.263 \\
ADFI (kg/DM) & $1.75^{\mathrm{a}}$ & $1.71^{\mathrm{a}}$ & $1.87^{\mathrm{a}}$ & $1.59^{\mathrm{b}}$ & $1.49^{\mathrm{b}}$ & 0.18 & $<.0001$ & 0.0047 & $<.0001$ \\
ADG (kg) & $0.85^{\mathrm{a}}$ & $0.89^{\mathrm{a}}$ & $0.81^{\mathrm{ab}}$ & $0.72^{\mathrm{c}}$ & $0.71^{\mathrm{c}}$ & 0.09 & $<.0001$ & 0.898 & 0.192 \\
FCR & $2.06^{\mathrm{d}}$ & $2.39^{\mathrm{a}}$ & $2.25^{\mathrm{a}}$ & $2.11^{\mathrm{c}}$ & $2.07^{\mathrm{d}}$ & 0.21 & $<.0001$ & 0.045 & $<.0001$ \\
\hline
\end{tabular}

Note. ${ }^{\mathrm{a}, \mathrm{b}}$ Within a row means with different superscripts $\operatorname{differ}(P<0.001),{ }^{1} \mathrm{CON}=$ Control diet; LLFPHE $=\mathrm{Low}$ liquid fermented potato hash with enzyme diet, LLFPH = Low liquid fermented potato hash without enzyme diet, HLFPH- High liquid fermented potato hash with enzyme diet, HLFPH $=$ High liquid fermented potato hash without enzyme diet. ${ }^{2} \mathrm{IW}=$ Initial weight, FW = Final weight; ADFI = Average daily feed intake, $\mathrm{ADG}=$ Average daily gain, $\mathrm{FCR}=$ Feed conversion ratio.

\section{Conclusion}

The varying levels of fermented liquid potato hash did not negatively affect nutrient composition of the diets. The use of exogenous enzyme during fermentation reduced the fibre fractions of the fermented liquid potato hash even though it was at the expense of energy content of the diets. The overall performance of pigs fed low inclusion levels of fermented liquid potato hash diets treated with or without enzyme improved growth performance of grower pigs. Therefore, this implies that FLPH might be an alternative feed source for growing pigs. More studies need to determine the optimum inclusion level of LFPH in pig diets, their impact on carcass quality and the cost benefit.

\section{Acknowledgements}

The Agricultural Research Council and Gauteng Department of Agriculture and Rural Development funded the study.

\section{References}

AOAC. (1990). Official Methods of Analysis (16th ed.). Association of Analytical Chemists, Washington DC, USA.

Brooks, P. H. (2008). Fermented liquid feed for pigs. CAB Rev. Perspect. Agric. Vet. Sci. Nutr. Nat. Resour., 3, 1-18. https://doi.org/10.1080/1745039X.2010.512725 
Brooks, P. H., Beal, J. D., Niven, S. J., \& Demeckova, V. (2003). Liquid feeding of pigs II: Potential for improving pig health and food safety. Anim. Sci. Pap. Rep., 21, 23-39. http://livestocklibrary.com.au/ handle/1234/19960

Canibe, N., \& Jensen, B. B. (2003). Fermented and no fermented liquid feed to growing pigs: Effect on aspects of gastrointestinal ecology and growth performance. J. Anim. Sci., 81, 2019-2031. https://doi.org/10.2527/ 2003.8182019x

Choct, M., Selby, E. A. D., Cadogan, D. J., \& Campbell, R. G. (2004). Effects of particle size, processing and dry or liquid feeding on performance of piglets. Aust. J. Agric. Res., 55, 237-245. https://doi.org/10.1071/ AR03105

de Lange, C. F. M., Zhu, C. H., Niven, S., Columbus, D., \& Woods, D. (2006). Swine liquid feeding: Nutritional considerations. Proc. Western Nutrition Conference, Winnipeg, MB, Canada (pp. 1-13).

Eun, J.-S., \& Beauchemin, K. A. (2007). Enhancing in vitro degradation of alfalfa hay and corn silage using feed enzymes. J. Dairy Sci., 90, 2839-2851. https://doi.org/10.3168/jds.2006-820

Fevrier, C., Bourdon, D., \& Aumaitre, A. (1992). Effects of level of dietary fibre from wheat bran on digestibility of nutrients, digestive enzymes and performance in the European Large White and Chinese Mei Shan pig. $J$. Anim. Physiol. Anim. Nutr. (Berl), 68, 60-72. https://doi.org/10.1111/j.1439-0396.1992.tb00618.x

Han, Y. K., Thacker, P. A., \& Yang, J. S. (2006). Effects of the duration of liquid feeding on performance and nutrient digestibility in weaned pigs. Asian-Austral J. Anim. Sci., 19, 396-401. https://doi.org/10.5713/ ajas.2006.396

Hoffman, L. C., Styger, E., Muller, M., \& Brand, T. S. (2003). The growth and carcass and meat characteristics of pigs raised in a free-range or converntional housing system. Asian-Australas J. Anim. Sci., 33, 166-175. https://doi.org/10.4314/sajas.v33i3.3770

Højberg, O., Canibe, N., Knudsen, B., \& Jensen, B. B. (2003). Potential rates of fermentation in digesta from the gastrointestinal tract of pigs: Effect of feeding fermented liquid feed. Appl. Environ. Microbiol., 69, 408-418. https://doi.org/10.1128/AEM.69.1.408-418.2003

Hong, T. T. T., Thuy, T. T., Passoth, V., \& Lindberg, J. E. (2009). Gut ecology, feed digestion and performance in weaned piglets fed liquid diets. Livest. Sci., 125, 232-237. https://doi.org/10.1016/j.livsci.2009.04.013

Kanengoni, A. T., Dzama, K., Chimonyo, M., Kusina, J., \& Maswaure, S. M. (2004). Growth performance and carcass traits of Large White, Mukota and their F1 crosses fed on graded levels of maize cobs. Animal Science, 78(1), 61-66. https://doi.org/10.1017/S1357729800053844

Kim, J. H., Heo, K. N., Odle, J., Han, I. K., \& Harrell, R. J. (2001). Liquid diets accelerate the growth of early weaned pigs and effects are maintained to market weight. J. Anim. Sci., 79, 427-434. https://doi.org/ $10.2527 / 2001.792427 \mathrm{x}$

Le Gall, M., Warpechowski, M., Jaguelin-Peyraud, Y., \& Noblet, J. (2009). Influence of dietary fibre level and pelleting on the digestibility of energy and nutrients in growing pigs and adult sows. J. Anim. Sci., 3, 352-359. https://doi.org/10.1017/S1751731108003728

Li, P. F., Xue, L. F., Zhang, R. F., Pioa, X. S., Zeng, Z. K., \& Zhan, J. S. (2011). Effects of Fermented Potato Pulp on Performance, Nutrient Digestibility, Carcass Traits and Plasma Parameters of Growing-finishing Pigs. Asian-Aust. J. Anim. Sci., 24(10), 1456-1463. https://doi.org/10.5713/ajas.2011.11169

Nkosi, B. D., \& Meeske, R. (2010). Effects of ensiling toatally mixed potato hash ration with or without heterofermentative bacterial inoculant on silage fermentation, aerobic stability, and growth performance of lambs. Anim. Feed Sci. Technol., 161, 38-48. https://doi.org/10.1016/j.anifeedsci.2010.07.015

Nkosi, B. D., Kanengoni, A. T., \& Thomas, R. S. (2011). Effects of ensiling total mixed potato hash ration with or without bacterial inoculation on silage fermentation and nutritive value for growing pigs. J. Anim. Vet. Adv., 10(13), 1667-1672. https://doi.org/10.3923/javaa.2011.1667.1672

Nkosi, B. D., Meeske, R., Langa, T., Motiang, M. D., Mutavhatsindi, T. F., Thomas, R. S., ... Baloyi, J. J. (2015). The influence of ensiling potato hash waste with enzyme/bacterial inoculant mixtures on the fermentation characteristics, aerobic stability and nutrient digestion of the resultant silages by rams. Small Rumin. Res., 127, 28-35. https://doi.org/10.1016/j.smallrumres.2015.04.013

Nkosi, B. D., Meeske, R., Van Der Merwe, H. J., \& Groenewald, I. B. (2010). Effects of homofermentative and heterofermentative bacterial silage inoculants on potato hash silage fermentation and digestibility in rams. 
Anim. Feed Sci. Technol., 157, 195-200. https://doi.org/10.1016/j.anifeedsci.2010.03.008

Okine, A., Hanada, M., Aibibula, Y., \& Okamoto, M. (2005). Ensiling of potato pulp with or without bacterial inoculants and its effect on fermentation quality, nutrient composition and nutritive value. Anim. Feed Sci. Technol., 121, 329-343. https://doi.org/10.1016/j.anifeedsci.2005.02.032

Plumed-Ferrer, C., \& Von Wright, A. (2009). Fermented pig liquid feed: nutritional, safety andregulatory aspects. J. Appl. Microb., 106, 351-368. https://doi.org/10.1111/j.1365-2672.2008.03938.x

Scholten, R. H. J., van der Peet-Schwering, C. M. C., den Hartog, L. A., Balk, M., Schrama, J. W., \& Verstegen, M. W. A. (2002). Fermented wheat in liquid diets: Effects on gastrointestinal characteristics in weanling piglets. J. Anim. Sci., 80, 1179-1186. https://doi.org/10.2527/2002.8051179x

Thomas, R. S., Nkosi, B. D., Umesiobi, D. O., Meeske, R., Kanengoni, A. T., \& Langa, T. (2010). Evaluation of potato hash silage from two bacterial inoculants and their effects on the growth performance of grower pigs. S. Afr. J. Anim. Sci., 40, 488-490.

Urriola, P. E., Shurson, G. C., \& Stein, H. H. (2010). Digestibility of dietary fiber in distillers' coproducts fed to growing pigs. J. Anim. Sci., 88, 2373-2381. https://doi.org/10.2527/jas.2009-2227

Wenk, C. (2001). The role of dietary fibre in the digestive physiology of the pig. Animal Feed Science and Technology, 90(1/2), 21-33. https://doi.org/10.1016/S0377-8401(01)00194-8

Xing, L., Chen, L. J., \& Han, L. J. (2009). The effect of an inoculant and enzymes on fermentation and nutritive value of sorghum straw silages. Bioresource Tech., 100, 488-491. https://doi.org/10.1016/j.biortech. 2008.06.017

Zhang, M., Su, F. W. R., Qi, W., \& He, Z. (2010). Ethanol production from high dry matter corncob using fed-batch simultaneous saccharification and fermentation after ombined pre-treatment. Bioresource Tech., 101, 4959-4964. https://doi.org/10.1016/j.biortech.2009.11.010

\section{Copyrights}

Copyright for this article is retained by the author(s), with first publication rights granted to the journal.

This is an open-access article distributed under the terms and conditions of the Creative Commons Attribution license (http://creativecommons.org/licenses/by/4.0/). 